\title{
Hjertesykes erfaringer gjør rehabiliteringen bedre
}

Brukerrepresentanter og fagpersoner samarbeider for å utvikle et enda bedre tilbud for hjerterehabilitering.

Brukerne har erfaringer som kan være nyttige og forståelige for andre hjertesyke.

\section{Tone Nøren}

Fysioterapeut og prosjektleder

Unicare Røros, rehabilitering

\section{Ingrid Bendixvold}

Sykepleier, prosjektmedarbeider og kvalitetsleder

Unicare Røros, rehabilitering

\section{André Vågan}

Seniorforsker

Nasjonal kompetansetjeneste for læring og mestring innen helse, Oslo universitetssykehus

\section{Line Merethe Oldervoll}

Professor og førsteamanuensis

Institutt for samfunnsmedisin og sykepleie, Fakultet for medisin og helsevitenskap, Norges teknisk-naturvitenskapelige universitet og Senter for krisepsykologi, Universitetet i Bergen 
I prosjektet «Brukeren i sentrum» har erfarne brukere, pårørende og fagpersoner samarbeidet om å videreutvikle hjerterehabiliteringstilbudet ved Unicare Røros. Systematisk arbeid med brukermedvirkning på tjenestenivå har vært et av suksesskriteriene. Denne artikkelen beskriver hvordan vi har arbeidet med brukermedvirkning i praksis, og sammenfatter resultater fra evalueringer av prosjektet.

«Brukeren i sentrum» er et treårig helseprosjekt finansiert av Stiftelsen Dam. Hovedmålet med prosjektet er å utvikle en tilpasset tjeneste som bidrar til økt mestring og livskvalitet i hverdagen for personer med hjertesykdom og deres pårørende.

Prosjektet er gjennomført ved Unicare Røros, som tilbyr rehabiliteringsopphold i spesialisthelsetjenesten til pasienter med hjertesykdom.

\section{Hjerterehabiliteringstilbudet ved Unicare Røros}

Målgruppen for hjerterehabilitering ved Unicare Røros er personer som har hatt hjerteinfarkt, har gjennomgått hjertekirurgi eller har andre hjertesykdommer.

Formålet med hjerterehabiliteringen er å sette deltakerne i stand til å håndtere fysiske og psykiske følger av sykdom og kunne fortsette med gode livsstilsvalg etter hjemkomst. Det dreier seg om å forebygge sykdomsutvikling, opprettholde livskvalitet og fremme mestring. Rehabiliteringen kan for mange være et vendepunkt, hvor livsstilsendringer er sentralt.

\section{Kilde: Unicare Røros}

Brukermedvirkning skal skje på flere nivåer, og nivåene reguleres av ulike lovverk på individnivå, tjeneste- og systemnivå og system- og politisk nivå. 
For å nå målet har vi arbeidet systematisk med brukermedvirkning på tjenestenivå og prøvd ut en modell hvor fagpersoner og brukerrepresentanter inngår i et likestilt samarbeid i planlegging, gjennomføring og evaluering av tilbud og tjenester for personer med helseutfordringer eller deres pårørende (1).

Samarbeidsmodellen innebærer involvering av fag-, erfarings- og brukerkunnskap og hvordan de utfyller hverandre (2). Modellen bidrar til at ulike perspektiver og kunnskap bringes inn i utviklingen av tjenesten eller tilbudet, slik at det best mulig tilpasses brukeres, pasienters og pårørendes behov og bidrar til å mestre hverdagen med helseutfordringer.

I prosjektet har vi lagt vekt på å styrke den helsepedagogiske kompetansen til fagpersoner og brukerrepresentanter for å tilrettelegge for læring og mestring hos pasientene (heretter kalt deltakerne). I tillegg har vi i prosjektet arbeidet med å utvikle og forbedre rehabiliteringsforløpet fra institusjon til hjemkommune for deltakerne.

I denne fagartikkelen retter vi oppmerksomheten mot brukermedvirkning på tjenestenivå. Vi vil først redegjøre for begrepet brukermedvirkning før vi beskriver hvordan vi har arbeidet med brukermedvirkning på tjenestenivå i praksis.

Til slutt vil vi oppsummere våre erfaringer fra arbeidet med samarbeidsmodellen samt resultater fra evalueringer av samarbeidet slik fagpersoner, brukerrepresentanter, personer med hjertesykdom og pårørende har opplevd det.

\section{Hva er brukermedvirkning?}

De siste årene har brukermedvirkning blitt fremhevet som et sentralt virkemiddel for å bedre kvaliteten $\mathrm{i}$ helse- og omsorgssektoren (1). 
- Begrepet brukermedvirkning er mangfoldig, og det eksisterer en rekke ulike definisjoner. Det er vanlig å skille mellom brukermedvirkning på tre nivåer, henholdsvis individ-, tjenesteog systemnivå.

- Brukermedvirkning på individnivå handler om den enkeltes rettigheter og muligheter til å ha innflytelse på sitt individuelle støtte- eller behandlingstilbud. Det betyr at den enkelte skal påvirke forhold som gjelder seg selv og egne behov.

- Brukermedvirkning på tjenestenivå innebærer at brukerrepresentanter inngår i et likestilt samarbeid med fagpersoner fra tjenesteapparatet. De er aktivt deltakende ved utveksling av kunnskap og erfaringer for å endre behandlingstilbud og tjenester.

- Brukermedvirkning på systemnivå er en arbeidsform hvor brukergrupper og brukerorganisasjoner involveres i planlegging av tiltak og tjenester som har allmenn betydning, og deltar i råd eller utvalg på styringsnivå.

\section{Kilde: mestring.no}

Hensikten med brukermedvirkning er å bidra til å styrke kvaliteten på tjenestene ved å tilpasse dem bedre til deltakeres og pårørendes behov. Brukermedvirkning på alle nivåer anses som viktig både blant myndigheter, fagpersoner og forskere og er godt forankret i lovverket $(3,4)$.

Fagmiljø og brukerorganisasjoner har utviklet veiledere for brukermedvirkning (5), og brukermedvirkning i forskning har blitt en obligatorisk del av forskningsprosessen (6).

\section{Involvering av brukere påvirker tjenesten}

Flere nylig publiserte artikler har sett på betydningen av brukermedvirkning på tjenestenivå. En litteraturstudie fra 2020 av 34 primærstudier unders $\varnothing$ kte innvirkningen av å aktivt involvere pasienter, brukere, brukerrepresentanter eller pårørende i utvikling av helsetjenester (7). 
Resultatene viste at involvering av brukerne $\mathrm{i}$

tjenesteutvikling har innflytelse på tjenestens form og innhold. Samarbeidsprosessen resulterte også i mange positive ringvirkninger både for fagpersoner og pasienter og brukere. For eksempel opplevde både fagpersoner og brukere å få $\varnothing \mathrm{kt}$ samarbeidskompetanse.

\section{«Resultatene viste at det var verdifullt for pasientene at både fagpersoner og erfarne brukere var kursledere sammen.»}

En annen litteraturstudie som inkluderte 47 studier, unders $\varnothing$ kte effekten og utbyttet av deltakelse i læringsog mestringstilbud for voksne pasienter (8).

Resultatene viste at det var verdifullt for pasientene at både fagpersoner og erfarne brukere var kursledere sammen.

Pasientene opplevde at erfarne brukere bidro til at informasjon ble enklere å forstå, og at hierarkiet mellom helsepersonell, brukere og pasienter ble mindre og bidro til å fremme støtte og gi håp.

En dansk randomisert kontrollert studie (9) har unders $\varnothing \mathrm{kt}$ om effekten av et hjerterehabiliteringstilbud bidro til at deltakerne fortsatte å være fysisk aktive etter at tilbudet var avsluttet.

I intervensjonsgruppen samarbeidet erfarne brukere på lik linje med helsepersonell i planleggingen og gjennomføringen av intervensjonen. I kontrollgruppen var det kun helsepersonell som underviste.

Etter avsluttet intervensjon, som varte i åtte uker, fortsatte signifikant flere pasienter fra intervensjonsgruppen å trene sammenliknet med kontrollgruppen. 


\section{Erfarne brukere har vært lite involvert i tilbud}

Til tross for $\varnothing \mathrm{kt}$ oppmerksomhet på brukermedvirkning de siste årene er vårt inntrykk at det er lite søkelys på brukermedvirkning på tjenestenivå gjennom aktiv involvering av erfarne brukere i planlegging, gjennomføring og evaluering av rehabiliteringstilbud.

Ved oppstart av prosjektet «Brukeren i sentrum» gjennomførte vi en kartlegging av de andre hjerterehabiliteringstilbudene ved private rehabiliteringsinstitusjoner i Norge.

Kartleggingen viste at av de 19 hjerterehabiliteringstilbudene vi kontaktet, arbeidet ingen systematisk med brukermedvirkning på tjenestenivå i utformingen eller forbedringen av sine tilbud.

\section{Et likeverdig samarbeid ligger til grunn}

Med utgangspunkt i en samarbeidsmodell for systematisk arbeid med brukermedvirkning utviklet av lærings- og mestringssentrene i spesialisthelsetjenesten (2), ønsket vi å videreutvikle hjerterehabiliteringstilbudet ved Unicare Røros.

Samarbeidsmodellen legger til grunn et likeverdig samarbeid mellom fagpersoner og erfarne brukere, hvor partene utfyller hverandre og bringer ulike perspektiver og kunnskap inn i utviklingen av tjenesten eller tilbudet (1). Vårt mål var å sikre at hjerterehabiliteringstilbudet er tilpasset målgruppens behov.

Vi etablerte en arbeidsgruppe bestående av brukerrepresentanter, ansatte fra tverrfaglig hjerteteam, representanter fra ledelsen, en representant fra Røros kommune og prosjektlederen. Arbeidsgruppen besto av 15 medlemmer, og sju av disse var brukerrepresentanter. 


\section{Hva er en brukerrepresentant?}

Med brukerrepresentant menes en som representerer brukere av tjenester. Det kan være en som selv lever med en sykdom, en som er nærperson til en som lever med sykdom, eller en som er ansatt eller tillitsvalgt i en brukerorganisasjon.

Kilde: Funksjonshemmedes Fellesorganisasjon (10)

\section{Hvordan rekrutteres brukerrepresentanter?}

For å rekruttere brukerrepresentanter henvendte vi oss til Landsforeningen for hjerte- og lungesykes lokallag $\mathrm{i}$ Røros (LHL Røros). Vi ønsket å verve ressurspersoner som lever med hjertesykdom, og deres nærpersoner, slik at vi kunne benytte både bruker-, pasient- og pårørenderepresentanter i utviklingen av hjerterehabiliteringstilbudet.

Vi kontaktet også noen brukerrepresentanter etter endt opphold på hjerterehabiliteringen og forespurte dem om de kunne tenke seg å delta.

\section{«Gjennom dialog fant vi sammen ut om de hadde de nødvendige egenskapene for å delta i prosjektet.»}

Alle brukerrepresentantene ble innkalt til en samtale der de fikk informasjon om prosjektet og hvilke oppgaver, roller og ansvar de skulle ha som brukerrepresentanter. Gjennom dialog fant vi sammen ut om de hadde de nødvendige egenskapene for å delta i prosjektet.

\section{Hvilke egenskaper må en brukerrepresentant ha?}


For å kunne være brukerrepresentant må man ha et bearbeidet og reflektert forhold til sin egen hjertesykdom eller det å være pårørende. Man må kunne sette ord på og formidle sine erfaringer, både utfordringer gjennom sykdomsforløpet og ulike tiltak man har gjort underveis for å mestre situasjonen sin.

Brukerrepresentanten må ha evne til å representere og snakke på vegne av målgruppen. Vi ønsket også at brukerrepresentantene hadde kunnskap om helsetjenesten og hvordan den er bygd opp, for å kunne påvirke diskusjoner og beslutninger $\mathrm{i}$ arbeidsprosessen til det beste for målgruppen de representerte.

\section{Fagkunnskap og erfaringskunnskap utfyller hverandre}

Tilrettelegging av trygge, gode møteplasser for arbeidsgruppen var nødvendig for å få til et fruktbart samarbeid (11). For å skape et likeverdig samarbeid mellom partene var det viktig å bygge gode relasjoner og tillit til hverandre samt avklare forventninger.

Det var tydelig for begge parter hvilke roller, oppgaver og ansvar de skulle ha i dette arbeidet. I tillegg utarbeidet vi kjøreregler for samarbeidet og et felles mandat. Et likeverdig samarbeid innebærer en felles forståelse for at fagpersoner og brukerrepresentanter bærer med seg ulik kompetanse, og at summen av disse skaper verdi i utviklingen av tjenesten (12).

I prosjektet har vi benyttet didaktisk relasjonsmodell som arbeidsverktøy. Modellen er mye brukt og er til hjelp for å finne svar på hva, hvorfor og hvordan man kan tilrettelegge for gode læringssituasjoner for brukere, pasienter og pårørende (13).

Det er en kompleks prosess å legge til rette for gode rehabiliteringstilbud, og det er mange faktorer som påvirker hverandre. Den didaktiske relasjonsmodellen (se figur 1) bidro til å forenkle komplekse prosesser ved å gi en oversikt over faktorer som er viktig å ta hensyn til ved opplæring av pasienter og pårørende. 


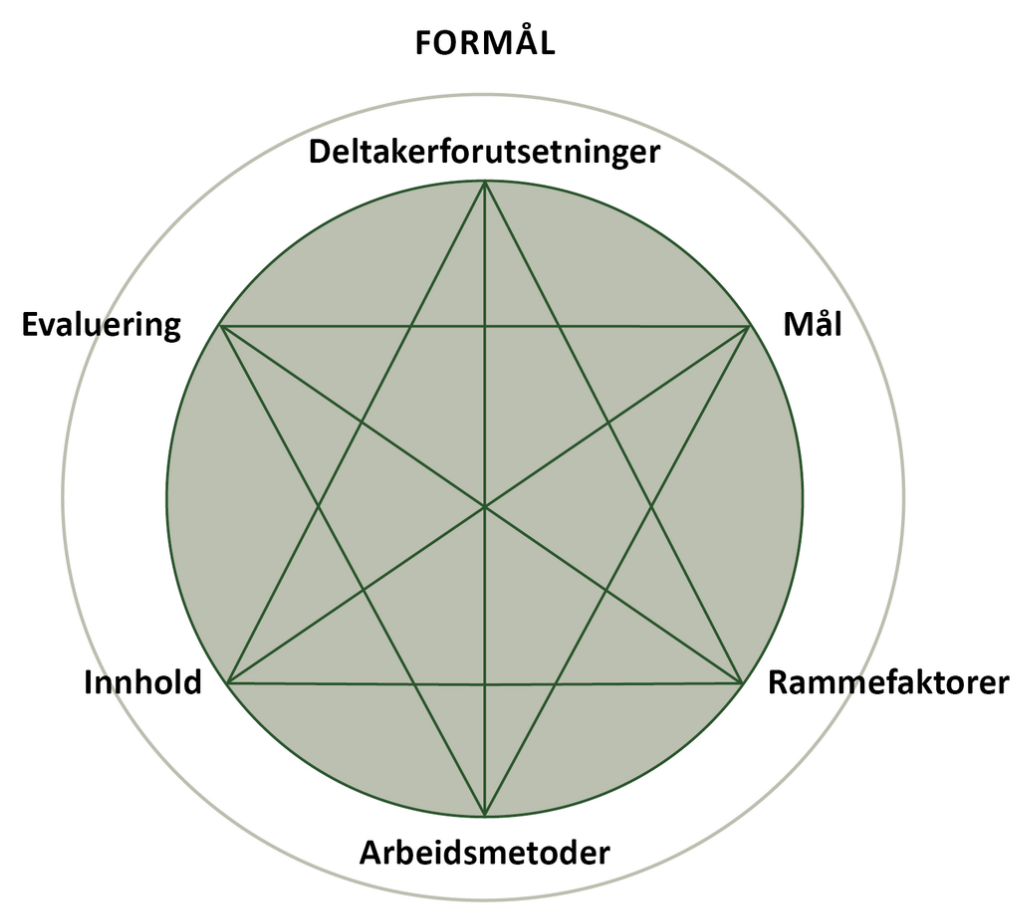

Den første oppgaven for arbeidsgruppen var å definere målgruppen og forstå deltakernes forutsetninger for læring. Hvem er deltakerne på hjerterehabiliteringen, hva er deres behov, og hvilke ønsker og ressurser har de?

Videre arbeidet vi med å avklare hovedmålet med hjerterehabiliteringstilbudet. Fantes det en fellesnevner som begge partene kunne enes om? For å finne svar på dette spørsmålet fikk brukerrepresentantene i oppdrag å snakke med minimum to andre personer med hjertesykdom eller pårørende.

Fagpersonene fikk i oppdrag å unders $\varnothing$ ke fag- og forskningslitteratur samt løfte frem erfaringer fra møtene de hadde hatt med målgruppen over tid. Det var enighet i arbeidsgruppen om at hovedmålet med hjerterehabiliteringen var å gi deltakerne trygghet $\mathrm{i}$ form av $\varnothing k t$ kunnskap, håp og motivasjon. 
Etter at målet var bestemt, arbeidet arbeidsgruppen videre med hvilke temaer og hvilket innhold tilbudet skulle bestå av. Informasjon om temaer som symptomer, følelser og reaksjoner, hjertestatus og behandling og praktisk hjelp og støtte til varige livsstilsendringer var viktig.

$\varnothing \mathrm{kt}$ kunnskap gjennom aktive læringsprosesser gir forståelse og motivasjon for den enkelte til å akseptere sin egen situasjon, forstå hva som har hendt, og la håpet om å leve så normalt som mulig vende tilbake, slik at hverdagsaktiviteter igjen kan spire og gro.

\section{Brukerrepresentantene fortalte om sine erfaringer}

Bruk av erfaringsinnlegg ble en sentral del av hvordan vi la til rette for læring, og var viktig for å oppnå hovedmålet for tilbudet. Brukerrepresentantene hadde dermed flere roller og oppgaver i samarbeidet, både som deltakere i arbeidsgruppen som planla tilbudet, og som deltakere med erfaringsinnlegg i selve tilbudet.

\section{Ny film om prosjektet}

Prosjektet «Brukeren i sentrum» har produsert en ny film som omhandler brukermedvirkning på tjenestenivå. Se filmen her.

Oppbyggingen av erfaringsinnleggene var tuftet på en felles mal som er mye anvendt i praksisfeltet, med en kort innledning om sykdomsforløp, mens hovedhensikten var å formidle vendepunktet: Hva var det som gjorde at «du kom deg på beina», hvilke endringer er gjort, og hvordan etterleves endringene nå i dag $(1)$ ?

Innholdet i historiene til de ulike brukerrepresentantene var forskjellige. En fellesnevner var at alle formidlet tanker, følelser og reaksjoner på det de hadde vært igjennom, og at de i dag lever bra til tross for hjertesykdommen. 
Den samme metoden benyttet vi for pårørende ved at pårørenderepresentanten delte sin historie. Gjennom prosjektet fikk vi prøve ut erfaringsinnleggene ved at brukerrepresentantene møtte deltakerne på hjerterehabilitering for å dele «sin historie».

\section{Begge partene lærte av samarbeidet}

Ved oppstarten av prosjektet var brukermedvirkning på tjenestenivå ukjent for arbeidsgruppen. Begge partene tilegnet seg viktige erfaringer fra samarbeidsprosessen.

For det første var det nødvendig å bruke tid både på å forstå hva samarbeidet skulle handle om, og å utvikle et samspill preget av likeverdighet. Det å ha og utvise respekt for hverandre mente de hadde vært en viktig forutsetning for å få dette til.

\section{«Samarbeidet ga et utbytte de mente de ikke ville fått hvis de hadde arbeidet hver for seg.»}

Partene rapporterte dessuten om en ekstragevinst ved å samarbeide. Samarbeidet ga et utbytte de mente de ikke ville fătt hvis de hadde arbeidet hver for seg. Gevinsten eller merverdien handlet primært om at de har fătt tilført nye perspektiver på hva som er viktig for å legge til rette for læring og mestring.

En av fagpersonene uttalte: «Samarbeidet med brukerrepresentantene har gitt økt kunnskap om hva som oppleves nyttig og godt når man har blitt rammet av hjertesykdom.»

En annen fagperson formulerte seg slik: «Brukere har 'kjent på kroppen' hvor systemet feiler. Det gjør at vi kan skreddersy et mer målrettet opplegg ut fra hva brukeren får med seg og har behov for.» 
En tredje fagperson mente at samarbeidet med brukerne har forbedret tilbudet og gjort at det blir mer treffsikkert for deltakerne. Vedkommende sa: «Vi får utvidet kunnskap og innsikt, og de hjelper oss til å bruke et forståelig språk - ikke med så mange fremmedord. Brukerens erfaring er gull!»

\section{Brukernes historier var gjenkjennelige}

Fagpersonell trakk spesielt frem erfaringsinnleggene som nyttige. De registrerte at erfaringer fra en som selv har opplevd det på sin egen kropp, er noe annet enn teoretisk kunnskap. Historiene som brukerrepresentantene delte, var ofte gjenkjennelige og bidro til å normalisere følelser og reaksjoner hos deltakerne.

Brukerrepresentantene fremsto som gode rollemodeller, som igjen kunne gi håp og tro på at «kan du klare det, kan jeg». Fagpersonene erfarte også at temaene som brukerrepresentantene løftet frem i erfaringsinnleggene, var betydningsfulle og fungerte som «døråpnere» for videre samtaler med deltakerne.

Brukerrepresentantene ga også positive tilbakemeldinger på det å dele sin historie. Blant annet verdsatte de det å holde innlegg som deltakerne kjenner seg igjen i, og som kan gi dem mer trygghet og motivasjon. De opplevde det som meningsfullt å bidra med erfaringer som kan komme andre til gode. De erfarte dessuten samarbeidet med fagpersoner som viktig for å kunne bidra til dialog med deltakerne.

\section{Deltakerne evaluerte erfaringsinnleggene}

For å få kunnskap om hvilken innvirkning brukerrepresentantenes aktive rolle hadde på deltakernes utbytte av tilbudet, ba vi om en tilbakemelding fra deltakerne og de pårørende om erfaringsinnleggene. 
I løpet av prosjektperioden fikk 324 deltakere og 80 pårørende anledning til å evaluere totalt 43 erfaringsinnlegg anonymt. Blant deltakerne var det flest menn, og gjennomsnittsalderen var 63 år. Blant de pårørende var det flest kvinner.

Hovedinntrykket fra tilbakemeldingene er at både deltakerne og de pårørende hadde et godt utbytte av erfaringsinnleggene. For det første rapporterte de at erfaringsinnleggene og møteplassene mellom brukereller pårørenderepresentanten og deltakerne eller de pårørende bidro til å normalisere deres egne reaksjoner fordi de kjente seg igjen i det andre fortalte.

\section{«Hovedinntrykket fra tilbakemeldingene er at både deltakerne og de pårørende hadde et godt utbytte av erfaringsinnleggene.»}

Andre deltakere trakk frem $\varnothing \mathrm{kt}$ trygghet og mestringsstrategier som et sentralt utbytte av erfaringsinnleggene. En deltaker fremhevet nytten av å høre om ulike mestringsstrategier som de erfarne brukerne fortalte om, for eksempel hvordan man kan «jobbe seg tilbake og venne seg til å se muligheter i stedet for begrensninger», som vedkommende uttalte.

En annen deltaker trakk frem verdien av å høre andre fortelle om vendinger i livet: «A høre at andre har klart det, gir meg tro på at det skal gå bra for meg også.»

Pårørende pekte også på betydningen av å bli sett og hørt. En av de pårørende sa: «Det er fint at det også er fokus på den som er partner/familie. Det kan nok bli glemt i prosessen, der alt dreier seg om pasienten.» Åpenhet om sin egen situasjon var et viktig tema for de pårørende. En av dem uttalte: «Det å høre andre erfaringer som både er like og ulike. Det er godt å dele.» 
Flere pårørende satte dessuten pris på at det ble satt ord på temaer som døden, og en uttrykte at det er viktig: «A ha et møte med andre pårørende. $\AA$ h $\varnothing r e$ deres opplevelser, erfaringer. Å diskutere tema som $\mathrm{d} \varnothing \mathrm{d} . »$

Slike tilbakemeldinger fra deltakerne og de pårørende indikerer at møtene med erfarne brukerrepresentanter bidrar positivt til trygghet, håp og mestringstro i hverdagen med sykdom.

\section{Veien videre}

På bakgrunn av positive erfaringer med samarbeidet og gode evalueringer fra både fagpersoner, brukerrepresentanter, deltakere og pårørende oppfordrer vi flere til å ta i bruk samarbeidsmodellen. Det gjelder ikke bare innen hjerterehabilitering, men innen rehabilitering og lærings- og mestringsvirksomhet generelt.

Modellen er tidligere positivt evaluert av flere aktører, blant annet fordi den beskriver hvordan man kan jobbe med brukermedvirkning i praksis, noe mange etterlyser. Det er også behov for mer forskning for å få bedre dokumentasjon av effekter gjennom randomiserte kontrollerte fors $\varnothing \mathrm{k}$.

\section{Referanser}

1. Vågan A, Heimest $\varnothing 1 \mathrm{~S}, \mathrm{~B} \varnothing$ rve H. En modell for brukermedvirkning innen læring og mestring. I: Vågan A, red. Helsepedagogiske metoder - teori og praksis. Oslo: Gyldendal; 2020. s. 22-40.

2. Hvinden K. Etablering av lærings- og mestringssentra - historie, grunnlagstenkning, innhold og organisering. I: Lerdal A, Fagermoen MS, red. Læring og mestring - et helsefremmende perspektiv i praksis og forskning. Oslo: Gyldendal Akademisk; 2011. s. 48-62. 
3. Lov 2. juli $1999 \mathrm{nr} .63$ om pasient- og

brukerrettigheter (pasient- og brukerrettighetsloven).

Tilgjengelig fra:

https://lovdata.no/dokument/NL/lov/1999-07-02-63 (nedlastet 13.08.2021).

4. Lov 15. juni $2001 \mathrm{nr} .93$ om helseforetak m.m. (helseforetaksloven). Tilgjengelig fra: https://lovdata.no/dokument/NL/lov/2001-06-1593\#KAPITTEL_1 (nedlastet 13.08.2021).

5. Kreftforeningen. Veileder i brukermedvirkning med kreftrammede og pårørende i fokus. Utgitt i samarbeid mellom Kreftforeningen og pasient- og likepersonsorganisasjonene. Oslo: Kreftforeningen; 2014.

6. Kjelsaas M. Brukernes stemme i forskningen. Michael Quarterly. 2020;17(24):115-78.

7. Olsson ABS, Strøm A, Haaland- Øverby M, Fredriksen K, Stenberg U. How can we describe impact of adult patient participation in health-service development? A scoping review. Patient Educ Couns. 2020;103(8):1453-66.

8. Stenberg U, Haaland-Øverby M, Fredriksen K, Westermann K, Kvisvik T. A scoping review of the literature on benefits and challenges of participating in patient education programs aimed at promoting selfmanagement for people living with chronic illness. Patient Educ Couns. 2016;99(11):1759-71.

9. Lynggaard V, Nielsen CV, Zwisler A-D, Taylor RS, May O. The patient education - learning and coping strategies - improves adherence in cardiac rehabilitation (LC-REHAB): a randomised controlled trial. Int J Cardiol. 2017;236:65-70.

10. Funksjonshemmedes Fellesorganisasjon (FFO). Når du representerer FFO - en introduksjon til brukerrepresentanter. Oslo: FFO; 2014. Skriftserie nr. o6/14. 
11. Strøm A. Samarbeid i Lærings- og

mestringssenteret - brukermedvirkning og

makt [doktoravhandling]. Oslo: Universitetet i Oslo; 2010.

12. Nasjonal kompetansetjeneste for læring og mestring (NK LMS). Arbeidsmåten i lærings- og mestringssentrene: standard metode 2011-versjon. Oslo: NK LMS; 2011.

13. Christiansen B, red. Helseveiledning. Oslo: Gyldendal Akademisk; 2013.

14. Hiim H, Hippe E. Undervisningsplanlegging for yrkesfaglærere. 3. utg. Oslo: Gyldendal Akademisk; 2009.

15. Bjørndal B, Lieberg S. Nye veier i didaktikken? En innføring i didaktiske emner og begreper. Oslo: Aschehoug; 1978. 